\title{
Faktor-Faktor yang Mempengaruhi Penyelesaian Masa Studi Program Pascasarjana di Institut Pertanian Bogor
}

\author{
Dina Yuniar*, Heti Mulyati, Eko Ruddy Cahyadi \\ Institut Pertanian Bogor, Bogor, Indonesia \\ *Corresponding Author. Email: dinayuniar@apps.ipb.ac.id
}

\begin{abstract}
Abstrak
Rata-rata penyelesaian masa studi program magister Sekolah Pascasarjana di Institut Pertanian Bogor kurang dari dua tahun (17,5\%). Oleh karena itu, faktor-faktor yang mempengaruhi baik dari aspek internal maupun eksternal perlu dikaji. Faktor internal berasal dari dalam diri mahasiswa yang meliputi kemampuan akademik dan motivasi. Faktor eksternal mencakup faktor lingkungan dan pembimbing saat menyelesaikan tugas akhir. Pengambilan data dan informasi menggunakan instumen kuesioner yang terstruktur terhadap lulusan program magister. Analisis menggunakan analisis deskriptif, analisis faktor, dan regresi linier berganda. Penyelesaian masa studi meliputi faktor-faktor kualitas pembimbingan, pelayanan dan lingkungan, kemampuan mahasiswa, motivasi, responsif serta gelar dan prestis. Analisis lebih lanjut menunjukkan penyelesaian masa studi sangat terkait dengan faktor-faktor eksternal yang berasal dari luar seperti layanan pendidikan dan faktor lingkungan, di antaranya lingkungan kampus yang bersih dan hijau, lingkungan belajar yang tenang dan nyaman. Responsif terhadap feedback dari pembimbing untuk segera memperbaiki tesis secara intens dan tepat waktu merupakan faktor internal.
\end{abstract}

Kata kunci: Masa Studi, Perguruan Tinggi, Eksternal, Internal, Analisis Faktor.

\section{Factors on Completing Study of Master Students in Graduate School, IPB University}

\begin{abstract}
Completion of the final assignment of the Postgraduate school master's program at the IPB University on average less than two years (17,5\%). This is the purpose of the research, namely to see the factors that influence the completion of the final task. The factors that influence the study period consist of internal and external factors. Internal factors originating from within the student themselves include academic ability and motivation. External factors come from outside such as environmental factors and mentors when completing the final task. Retrieval of data and information in this study using a structured questionnaire instrument for graduates of the IPB University's Graduate School Masters program. The analysis uses descriptive analysis, factor analysis, and multiple linear regression. Completion of the study period includes factors of coaching quality, service and environment, student ability, motivation, responsiveness and degree and prestige. Further analysis shows that the completion of studies is closely related to external factors originating from outside such as education services and environmental factors, including a clean and green campus environment, a quiet and comfortable learning environment. Responsiveness to feedback from the counselor to immediately correct the thesis in an intense and timely manner is an internal.
\end{abstract}

Keywords: Complete a Study, Postgraduate, External, Internal, Factor Analysis. 


\section{PENDAHULUAN}

Sekolah Pascasarjana (SPs) Insitut Pertanian Bogor (IPB) didirikan pada tahun 1975 sebagai unsur pelaksana akademik yang mengkoordinasikan pelaksana akademik tersebut serta dapat menyelenggarakan atau mengelola program magister (S-2) dan doktor (S-3) yang bersifat multidisiplin, interdisiplin, dan/atau transdisiplin. SPs IPB hingga tahun 2018 memiliki 117 Program Studi yang terdiri dari 73 program magister dan 44 program doktor, dengan jumlah mahasiswa lebih dari 4.686 orang yang terdiri dari 3.448 orang mahasiswa program magister dan 1.238 orang mahasiswa progam doktor (Laporan Kinerja SPs IPB 2019). (Sistem Informasi Akademik SPs IPB)

Jumlah mahasiswa Program Magister lebih besar dari program doktor (70\%). Jumlah lulusan program magister tahun 2011 sampai dengan 2017 sebanyak 4.075 orang. Lulusan memiliki rata-rata IPK $>=3,50$. Namun, permasalahan yang dihadapi adalah sebagian besar mahasiswa mengalami keterlambatan penyelesaian masa studi. Mahasiswa yang mampu menyelesaikan studi kurang dari 2 (dua) tahun hanya 17.5 persen.

Menurut Mohammadi dan Sharififfar (2016, p.1), faktor-faktor yang mempengaruhi lama studi mahasiswa bersumber dari faktor internal dan eksternal. Faktor-faktor penghambat dan pendukung yang mempengaruhi mahasiswa S2 dalam penulisan tesis berasal dari dalam kampus dan luar kampus (Sudira, Soenarto \& Pardjono, 2015, p.67)

Putri dan Safira (2013, p.3-4) menambahkan bahwa faktor internal adalah faktor-faktor hambatan dalam diri yang mempengaruhi saat menyelesaikan tugas akhir. Faktor internal meliputi kemampuan akademik, sulit menentukkan judul, kesulitan mencari literatur dan bahan bacaan, kemampuan menulis, kurang percaya diri, sulit menerima kritik, sifat malas, dan perbedaan gender. Faktor eksternal didefinisikan sebagai faktor-faktor hambatan dari luar saat menyelesaikan tugas akhir yaitu pembimbing, lingkungan penelitian (Zaaba, Gunggut, Arapa, Aning, 2015, p.182, Sakurai, Pyhalto, Ylanne, 2012, p.108), dan beasiswa (Abiddin dan Ismail, 2013, p.17).

Earl-Novell (2006, p.46) menemukan bahwa terdapat sejumlah faktor yang berbeda-beda menjadi penghambat kelulusan. Dalam penelitian internasional yang lebih ekstensif oleh McCormack (2005, p.234), faktor-faktor yang berhubungan dengan penyelesaian studi pendidikan tinggi, diantaranya faktor-faktor kelembagaan (Seagram, Gould, Pyke, 1998,p.321; Mugimu, Nsubuga, Jacob, 2009, p.336; Shariff, Kamal, Ramli \& Ahmad, 2015, p.261), pengaturan pengawasan (Zaaba, Gunggut, Arapa, Aning, 2015, p.184; Seagram, Gould, Pyke, 1998, p.324; Smith, Cameron \& Quigg, 2017, p.4), dan faktor pribadi siswa (Ihsan dan Zaki, 2015, p.29; Shariff, Kamal, Ramli \& Ahmad, 2015, p.262). Latona dan Brown (2001) mengkaji faktor-faktor penghambat penyelesaian studi pendidikan tinggi meliputi: faktor institusional (kedisiplinan, karakteristik dan rasa kepemilikan), pengaturan pembimbingan (feedback, frekuensi pertemuan, hubungan, dan memulai lebih awal) dan karakteristik kandidat (kualifikasi masuk, sifat penerimaan (full time atau part time), dan faktor psikologi.

Hubungan antara mahasiswa dan pembimbing merupakan prediktor yang signifikan untuk keberhasilan dan kegagalan dalam penelitian (Armstrong, Allinson, \& Hayes, 2004, p.45). Hubungan yang positif antara mahasiswa dan pembimbing sangat penting (Bourke, Holbrook \& Farley, 2004, p.4; Zaaba, Gunggut, Arapa, Aning, 2015, p.184), karena kualitas interaksi dan kualitas pribadi dari pembimbing merupakan faktor penting untuk penyelesaian studi (Latone dan Browne 2001).

Tujuan penelitian ini adalah untuk menganalisis faktor-faktor penyebab lamanya penyelesaian masa studi mahasiswa program magister SPs IPB. Hasilnya diharapkan dapat dijadikan rujukan dalam memperpendek penyelesaian masa studi mahasiswa, khususnya program magister. 


\section{METODE PENELITIAN}

Penelitian ini menggunakan metode kuantitatif melalui pengisian kuesioner dari lulusan program magister SPs IPB tahun masuk 2013-2017. Penelitian dilaksanakan pada bulan Februari - April 2019.

Pengambilan data dan informasi menggunakan instrumen kuesioner yang terstruktur berupa pertanyaan tertutup dan semi terbuka. Jawaban beberapa pertanyaan terstruktur dibuat menggunakan skala Likert (1-5).Faktor-faktor tersebut diantaranya akademik, motivasi (faktor internal) dan faktor lingkungan dan pembimbingan (faktor eksternal) yang diuraikan sebagai berikut:

\begin{tabular}{|c|c|c|}
\hline $\mathrm{X} 1$ & : & Lingkungan kampus yang bersih dan hijau \\
\hline $\mathrm{X} 2$ & : & Lingkungan belajar yang tenang dan nyaman \\
\hline $\mathrm{X} 3$ & : & Dukungan konseling dan karir \\
\hline $\mathrm{X} 4$ & : & Tersedianya perpustakaan yang memadai \\
\hline X5 & : & Tersedianya sarana pembelajaran (Meja, kursi, LCD, white board, spidol dll) \\
\hline X6 & : & Tersedianya akses internet yang cepat \\
\hline $\mathrm{X} 7$ & : & Tersedianya layanan administrasi yang mudah diakses \\
\hline $\mathrm{X} 8$ & : & Sering diselenggarakan diskusi, Workshop, dan seminar di kampus \\
\hline X9 & : & Dosen pembimbing melibatkan untuk membuat keputusan penelitian \\
\hline $\mathrm{X} 10$ & $:$ & Saya dilibatkan oleh dosen pembimbing dalam penelitian \\
\hline $\mathrm{X} 11$ & : & Keterampilan interpersonal mahasiswa dalam komunikasi lisan \\
\hline $\mathrm{X} 12$ & : & Keterampilan teknik menulis mahasiswa \\
\hline $\mathrm{X} 13$ & : & Keterampilan kerja independen dan multitasking \\
\hline $\mathrm{X} 14$ & : & $\begin{array}{l}\text { Mahasiswa terampil dalam menggunakan internet dan sistem informasi di kampus dalam } \\
\text { mencari literatur }\end{array}$ \\
\hline $\mathrm{X} 15$ & : & Mahasiswa menerima masukan dengan cepat dan tepat \\
\hline $\mathrm{X} 16$ & $:$ & Mahasiswa menulis laporan penelitian dengan jelas dan ringkas \\
\hline $\mathrm{X} 17$ & : & Pembimbing bijaksana dalam menyikapi kesulitan mahasiswa dalam penelitian \\
\hline $\mathrm{X} 18$ & $:$ & Pembimbing memilliki ilmu pengetahuan yang luas \\
\hline $\mathrm{X} 19$ & : & Pembimbing dikenal perhatian terhadap kemajuan studi mahasiswa \\
\hline $\mathrm{X} 20$ & : & Pembimbing memiliki komitmen untuk mempermudah proses pembimbingan \\
\hline $\mathrm{X} 21$ & : & Pembimbing membantu mengarahkan materi penelitian \\
\hline $\mathrm{X} 22$ & : & Mahasiswa intens seminggu sekali mengikuti bimbingan \\
\hline $\mathrm{X} 23$ & : & Mahasiswa memperoleh feedback yang kritis dan konstruktif \\
\hline $\mathrm{X} 24$ & : & Mahasiswa mudah menjalin komunikasi dengan pembimbing \\
\hline $\mathrm{X} 25$ & : & Mahasiswa memperoleh kejelasan panduan bimbingan \\
\hline $\mathrm{X} 26$ & : & Mahasiswa memberikan hasil perbaikan tesis tepat waktu ke pembimbing \\
\hline $\mathrm{X} 27$ & : & $\begin{array}{l}\text { Mahasiswa termasuk mahasiswa yang ulet dalam memperbaiki segera feedback dari } \\
\text { pembimbing }\end{array}$ \\
\hline $\mathrm{X} 28$ & : & Mahasiswa melanjutkan studi S2 untuk mencari gelar dan prestis \\
\hline $\mathrm{X} 29$ & : & Mahasiswa melanjutkan studi S2 untuk meningkatkan kompetensi dan kapasitas intelektual \\
\hline $\mathrm{X} 30$ & : & Mahasiswa melanjutkan studi S2 karena memperoleh beasiswa \\
\hline $\mathrm{X} 31$ & : & Mahasiswa memperoleh dukungan penuh dari keluarga \\
\hline $\mathrm{X} 32$ & : & Mahasiswa gigih, bertanggung jawab, dan berkomitmen \\
\hline X33 & : & Mahasiswa senang menulis dan meneliti \\
\hline $\mathrm{X} 34$ & $:$ & Mahasiswa bangga sebagai mahasiswa S-2 IPB \\
\hline
\end{tabular}

Penyebaran kuesioner dilakukan melalui 2 (dua) cara yaitu menggunakan google form yang disebar kepada lulusan program magister SPs IPB menggunakan whatsapp langsung ke responden, dan melalui sekretariat program studi untuk dikirimkan ke lulusan program studi sesuai kriteria yang ditetapkan. Pertanyaan meliputi faktor internal dan eksternal yang diuraikan ke dalam 34 variabel.

Metode pengambilan contoh yang dilakukan menggunakan proportional sampling dengan mempertimbangkan unsur-unsur atau kategori dalam populasi penelitian (Arikunto, 2006, p.116). Jumlah contoh yang diambil menggunakan rumus Slovin supaya dapat mewakili 
populasi dengan toleransi kesalahan 5\% sebanyak 364 orang. Contoh diperoleh dari data lulusan Program Magister SPs IPB tahun masuk 2013 sampai dengan 2017 sebanyak 4.075 orang lulusan.

\section{Teknik Pengolahan dan Analisis}

Data primer dari kuesioner dan wawancara diolah dengan analisis deskriptif dengan Microsoft Excel 2013. Selain itu dilakukan analisis faktor. Pengolahan data dilakukan dengan Statistical Package for the Social Science (SPSS) versi 24.

Uji Validitas dan Uji Reliabilitas dilakukan dengan memberikan kuesioner kepada 30 responden. Selanjutnya uji tersebut dilakukan kepada 364 responden. Berdasarkan uji validitas kuesioner, variabel-variabel penelitian ini valid. Uji validitas diperoleh dengan membandingkan $r$ tabel untuk degree offreedom $(\mathrm{df})=364$, jika alpha 0,05 . $r$ hitung lebih besar dari pada $r$ tabel maka butir pertanyaan dalam kuesioner dinyatakan valid. Uji reliabilitas dilihat dari nilai cronbach alpha.

Analisis faktor merupakan analisis statistik multivariat yang digunakan untuk mengambarkan pola hubungan antar variabel yang mendasari terbentuknya variable baru yang tidak terukur, atau disebut variabel laten atau faktor (Asra, Utomo, Asikin \& Pusponegoro, 2017, p.76).

Output nyata dari analisis faktor ini adalah faktor yang paling dominan yang mempengaruhi masa studi mahasiswa program magister SPs IPB. Sekumpulan variabel dikelompokan dengan mengukur korelasi pada setiap variabel, kemudian menempatkan setiap variabel yang saling berkorelasi tinggi pada satu faktor.

Berdasarkan Santoso (2014, pp. 59-62), prosedur dalam melakukan analisis ini meliputi pengujian kecukupan sampel melalui indeks Kaiser Meyer Olkin (KMO) dan nilai signifikansi Bartlett's Test of Sphericity, menguji Measure of Sampling Adequacy (MSA) untuk mengetahui apakah variabel yang digunakan sudah memenuhi untuk dianalisis lebih lanjut, kemudian melakukan ekstraksi variable dengan metode Principal Component Analysis (PCA).

Proses inti dari analisis faktor dengan melakukan proses ekstraksi variabel (factoring) terhadap sekumpulan variabel yang sudah ada. Metoda yang digunakan adalah PCA berdasarkan nilai eigen lebih besar dari satu. Setelah mendapatkan jumlah faktor kemudian dilakukannya rotasi faktor dari component matrix yang terbentuk untuk mendapatkan faktorfaktor dengan loading faktor yang lebih jelas untuk interpretasi.

Proses selanjutnya dianalisis menggunakan regresi linier berganda, uji t, uji $\mathrm{F}$ dan uji asumsi klasik dengan SPSS. Penelitian yang sama untuk melihat pengaruh dalam Syakir dan Pardjono (2015, p. 235), menggunakan analisis linier berganda. Hasil pengolahan data kemudian dianalisis dan diinterpretasikan secara deskriptif. Model regresi lama masa studi mahasiswa dievaluasi menggunakan uji asumsi dan uji statistik.

Model regresinya sebagai berikut:

$Y=\beta_{0}+\beta_{1} X_{1}+\beta_{2} X_{2}+\beta_{3} X_{3}+\beta_{4} X_{4}+\beta_{5} X_{5}++\beta_{6} X_{6}+\beta_{7} X_{7}+\varepsilon$

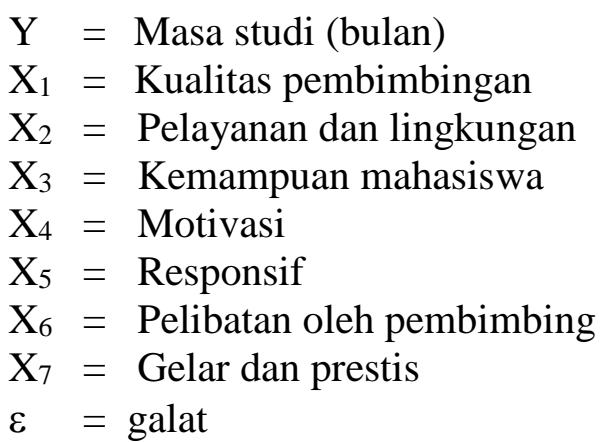




\section{Uji Asumsi Klasik}

Analisis dengan regresi linier berganda dilakukan setelah pengujian klasik yang terdiri atas uji normalitas, uji homoskedastisitas, dan uji multikolinieritas. Hal ini dilakukan agar dapat dilakukan perbaikan apabila terjadi penyimpangan dalam pengujian asumsi klasik. Untuk memastikan bahwa sebuah sebaran data berdistribusi normal, maka perlu dilakukan ujji normalitas.

Uji heterokedastisitas dilakukan untuk mengetahui bahwa pada model regresi terjadi varian data-data yang bersangkutan berbeda secara signifikan. Uji heteroskedastisitas dalam penelitian ini dilakukan dengan melihat grafik Scatter-Plot antara nilai prediksi variabel terkait (ZPRED) dengan residuaya (SRESID). Untuk mendeteksi adanya heteroskedastisitas dapat dilakukan dengan melihat grafik scatterplot antara nilai prediksi variabel dependen dengan residualnya (Ghozali, 2011). Uji multikolinieritas terjadi jika antar variabel independen saling berkorelasi secara signifikan. Multikolinieritas terjadi dengan dideteksi oleh Tolerance Value dan Variance Inflation Factor.

\section{Menganalisa Nilai Koefisien Determinasi (R-sqr)}

Analisis terhadap nilai R-Sqr dapat diartikan sebagai suatu nilai yang mengukur proporsi atau variasi total di sekitar nilai tengah $Y$ yang dapat dijelaskan oleh model regresi. Nilai R-Sqr berkisar $0<\mathrm{R}-\mathrm{Sqr}<1$.

\section{Uji Model Regresi}

Uji model regresi dilakukan dengan 2 (dua) macam, yaitu:

1. Uji serentak (Uji $F$ )

Uji serentak merupakan uji terhadap nilai-nilai koefisien regresi (b) secara bersama-sama atau keseluruhan dengan hipotesa:

$\mathrm{H}_{0}: \beta 1=\beta 2=\ldots=\beta \mathrm{p}=0$ (hipotesis nol dalam sebuah uji $F$ menyatakan bahwa semua koefisien dalam sebuah persamaan adalah sama dengan nol)

$\mathrm{H}_{\mathrm{a}}$ : Minimal ada $1 \beta \neq 0$ (hipotesis dalam sebuah uji f menyataan bahwa salah satu atau lebih koefisien dalam sebuah persamaan adalah tidak sama dengan nol) Statistik uji yang dipakai untuk melakukan uji serentak ini adalah statistik uji F.

Statistik Uji F untuk mencari F hitung:

$$
F_{\text {hitung }}=\frac{J K R / k}{J K G /(n-k-1)}
$$

Dimana:

JKR : Jumlah Kuadrat Regresi

JKG : Jumlah Kuadrat Galat

$\mathrm{k} \quad$ : Banyaknya peubah penjelas

n : Banyaknya data

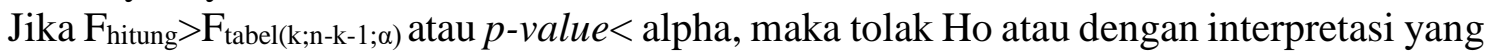
sama diperoleh bahwa minimal ada satu dari peubah penjelas yang berpengaruh nyata terhadap peubah respon. Kesimpulan tersebut mengindikasikan bahwa peubah penjelas berpengaruh secara bersamaan terhadap respon.

2. Uji individu (Uji t)

Jika hasil pada uji serentak (uji $F$ ) menunjukkan bahwa $\mathrm{H}_{0}$ ditolak, maka perlu dilakukan uji individu atau uji satu-satu prediktor yang sangat berpengaruh nyata. Hipotesa yang digunakan adalah:

$\mathrm{H}_{0}: \beta \mathrm{i}=0$ ( Hipotesis nol dalam sebuah uji $t$ menyatakan bahwa semua koefisien dalam sebuah persamaan adalah sama dengan nol) 
$\mathrm{H}_{\mathrm{a}}: \beta \mathrm{i} \neq 0$ ( Hipotesis satu dalam sebuah uji $t$ menyatakan bahwa salah satu atau lebih koefisien dalam sebuah persamaan adalah tidak sama dengan nol)

Untuk pengujian ini digunakan statistik uji $t$. Rumusan untuk mencari nilai $t_{\text {hitung: }}$

$t_{\text {hitung }}=\frac{b_{i}-\beta_{i}}{S_{b_{i}}}$

Dimana:

$b_{i} \quad$ : Dugaan koefisien regresi ke - i

$\beta_{\mathrm{i}} \quad$ : Parameter regresi ke $-\mathrm{i}$ yang di hipotesiskan

$\mathrm{S}_{\mathrm{bi}} \quad$ : Simpangan baku dari $\mathrm{b}_{\mathrm{i}}$

Jika $\left|t_{\text {hitung }}\right|>\mathrm{t}_{\text {tabel }(\alpha / 2 ; n-k-1)}$ atau nilai $p$-value $<$ alpha, maka tolak Ho, sehingga dengan interpretasi yang sama memaknai kesimpulan bahwa peubah penjelas ke-i berpengaruh nyata terhadap peubah respon.

\section{HASIL PENELITIAN DAN PEMBAHASAN}

\section{Karakteristik Responden}

Karakteristik responden disajikan berdasarkan jenis kelamin, proporsi responden laki-laki dan perempuan sebesar 47,24\% dan 52,75\%. Berdasarkan pekerjaan responden saat diterima di SPs IPB sudah bekerja dan belum bekerja masing-masing sebesar $50 \%$. Jenis pekerjaan responden yang telah bekerja saat diterima di SPs IPB sebagai Pegawai Negeri Sipil (PNS) sebesar 47,80\% dan Non PNS sebesar 52,20\%. Proporsi berdasarkan sumber pembiayaan adalah Non Beasiswa $(43,13 \%)$ dan Beasiswa $(56,87 \%)$. Berdasarkan pengalaman bekerja responden sampai saat ini, kurang dari satu tahun (25,00\%), 1 - 5 tahun $(31,87 \%), 5-10$ tahun $(17,58 \%)$ dan lebih dari 10 tahun $(14,56 \%)$. Sementara sebesar $10,99 \%$ responden belum bekerja.

Uji validitas kuesioner, variabel-variabel penelitian ini valid. Uji reliabilitas dilihat dari nilai cronbach alpha. Nilai cronbach alpha sebesar 0,906, maka variabel-variabel dalam pertanyaaan dapat dinyatakan reliabel. Tabel 1 menyajikan jumlah responden berdasarkan fakultas dan Program Multidisiplin yang ada di SPs IPB, serta berdasarkan responden yang lulus tepat waktu dan tidak tepat waktu. Responden yang tepat waktu adalah masa studinya sampai dengan 24 bulan, sedangkan masa studi yang tidak tepat adalah lebih dari 24 bulan.

Tabel 1. Jumlah responden berdasarkan masa studi

\begin{tabular}{lccc}
\hline \multirow{2}{*}{ Kelompok Fakultas } & \multicolumn{2}{c}{ Jumlah Contoh } & \multirow{2}{*}{ Jumlah } \\
\cline { 2 - 4 } & Tepat Waktu & Tidak Tepat Waktu & 54 \\
Fakultas Pertanian (FAPERTA) & 12 & 42 & 18 \\
Fakultas Kedokteran Hewan (FKH) & 7 & 11 & 50 \\
Fakultas Perikanan dan Ilmu Kelautan (FPIK) & 7 & 42 & 18 \\
Fakultas Peternakan (FAPET) & 6 & 12 & 22 \\
Fakultas Kehutanan (FAHUTAN) & 4 & 19 & 35 \\
Fakultas Teknologi Pertanian (FATETA) & 4 & 31 & 79 \\
Fakultas Matematika dan Ilmu Pengetahuan Alam & 12 & 68 & 44 \\
(FMIPA) & 9 & 35 & 22 \\
Fakultas Ekonomi dan Manajemen (FEM) & 2 & 20 & 23 \\
Fakultas Ekologi Manusia (FEMA) & 1 & 22 & 364 \\
Program Studi Multidisiplin & 64 & 300 & \\
\hline
\end{tabular}




\section{Karakteristik Analisis Faktor}

Tabel 2 menunjukkan hasil analisis faktor pertama melibatkan 34 indikator, menunjukkan hasil uji KMO, Bartlett's Test of Sphericity dan nilai Anti-Image Correlation. Nilai KMO dan Bartlett Test sebesar 0,901 dengan signifikasi 0,000 menyatakan bahwa masing-masing variabel memiliki kecukupan sampel untuk dapat dilakukan analisis faktor.

Tabel 2. Nilai KMO dan bartlett test untuk variabel individual

\begin{tabular}{lrr}
\hline Kaiser-Meyer-Olkin Measure of Sampling Adequacy &, 901 \\
\hline Bartlett's Test of Sphericity & Approx. Chi-Square & 5838,493 \\
\cline { 2 - 3 } & $\mathrm{df}$ & 561 \\
\cline { 2 - 3 } & Sig. &, 000 \\
\hline
\end{tabular}

Tabel 3. Komunalitas variabel penelitian

\begin{tabular}{cr}
\hline Anti-image Correlation & (MSA) \\
\hline X1 &, 827 \\
\hline X2 &, 891 \\
\hline X3 &, 917 \\
\hline X4 &, 937 \\
\hline X5 &, 937 \\
\hline X6 &, 888 \\
\hline X7 &, 873 \\
\hline X8 &, 940 \\
\hline X10 &, 886 \\
\hline X11 &, 827 \\
\hline X12 &, 920 \\
\hline X13 &, 883 \\
\hline X14 &, 908 \\
\hline X15 &, 908 \\
\hline X16 &, 895 \\
\hline X17 &, 925 \\
\hline &, 939 \\
\hline
\end{tabular}

Selanjutnya nilai Anti-Image-Correlation yang terkecil direkomendasikan untuk tidak diikutkan pada analisis faktor berikutnya (Tabel 3). Pada variabel 30 (X30) sebesar 0,435 yang tidak memenuhi kriteria untuk analisis tahap lanjutan dalam analisis faktor. Kemudian variabel X30 yaitu: saya bersekolah karena memperoleh beasiswa, direkomendasikan untuk mengeluarkan variabel X30 tersebut.

Hasil analisis faktor tahap kedua dilakukan dengan tidak mengikutkan item faktor X30. Diperoleh hasil nilai KMO dan Bartlett Test sebesar 0,904 dengan signifikasi 0,000 sehingga secara keseluruhan dapat dianalisis lebih lanjut. Hasil ekstraksi faktor awal menghasilkan tujuh komponen. Artinya ada tujuh faktor terbentuk dari 33 variabel yang dapat diolah dengan variansi kumulatif 62,09\% (Tabel 4).

Nilai Eigen menunjukkan kepentingan relatif masing-masing faktor dalam menghitung 33 variabel yang dianalisis. Tujuh faktor yang terbentuk tersebut memiliki nilai Eigen di atas 1. Untuk 8 sampai 33 faktor lainnya memiliki nilai Eigen di bawah 1, sehingga proses factoring berhenti pada tujuh faktor.

Proses inti dari analisis faktor dengan melakukan proses ekstraksi variabel (factoring) terhadap sekumpulan variabel yang sudah ada. Dimana metoda yang digunakan adalah PCA berdasarkan nilai eigen lebih besar dari satu. Hasil ekstraksi faktor awal menghasilkan tujuh komponen. Artinya ada tujuh faktor terbentuk dari 33 variabel yang dapat diolah dengan variansi kumulatif 62,09\% (Tabel 4). 
Tabel 4. Nilai akar ciri dan presentase variansi kumulatif faktor

\begin{tabular}{cccc}
\hline Komponen & \multicolumn{3}{c}{ Nilai Eigen } \\
\cline { 2 - 4 } & Jumlah & \% Varians & \% Kumulatif \\
\hline 1 & 9,737 & 29,506 & 29,506 \\
\hline 2 & 3,090 & 9,363 & 38,869 \\
\hline 3 & 2,536 & 7,684 & 46,553 \\
\hline 4 & 1,670 & 5,060 & 51,613 \\
\hline 5 & 1,252 & 3,793 & 55,406 \\
\hline 6 & 1,188 & 3,599 & 59,005 \\
\hline 7 & 1,018 & 3,086 & 62,090 \\
\hline
\end{tabular}

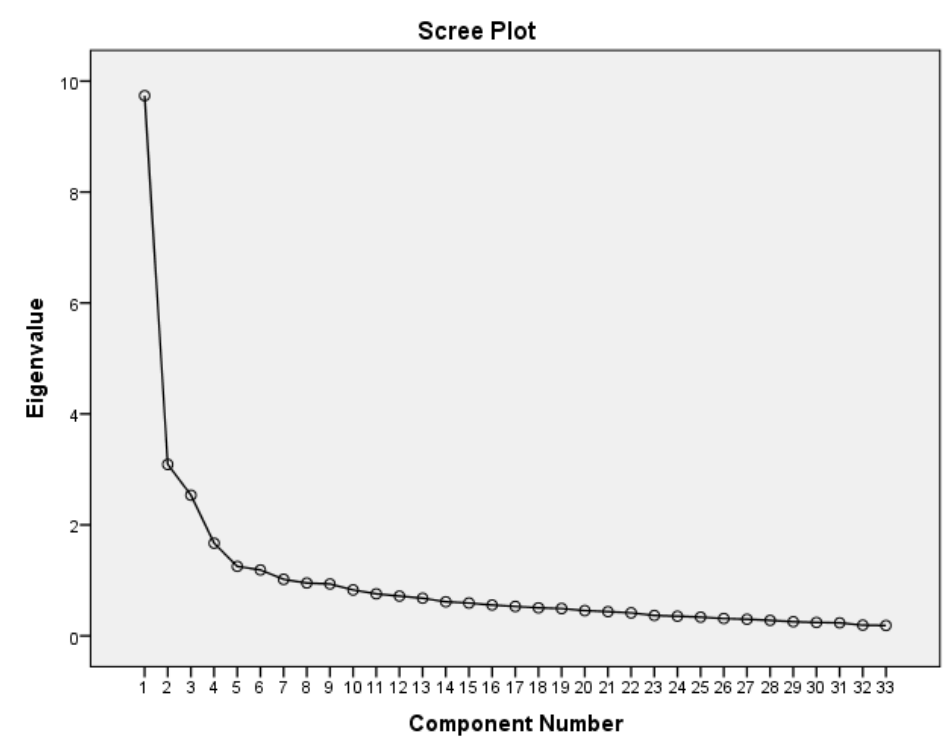

Gambar 1. Scree Plot nilai akar ciri dan identitas banyaknya faktor

Berbeda dengan varians total yang diperoleh dengan perhitungan angka, Scree Plot merupakan tampilan jumlah faktor yang didapat dengan grafik (Gambar 1). Terlihat bahwa dari satu ke dua faktor, dua ke tiga faktor dan seterusnya hingga enam ke tujuh faktor diperlihatkan dengan arah garis menurun yang cukup tajam. Faktor delapan merupakan titik yang terakhir pada kurva yang awalnya tampak curam kemudian menjadi landai. Hasil ini menunjukkan bahwa tujuh faktor direkomendasikan untuk meringkas ke-33 item faktor tersebut.

Nilai loading faktor perlu dirotasi agar masing-masing variabel berkorelasi kuat hanya pada satu faktor. Hal ini menyebabkan sulitnya menginterpretasikan faktor-faktor tersebut. Hasil dari rotasi faktor tersebut menunjukkan bahwa nilai-nilai loading faktor diantara variabel dengan beberapa faktor telah cukup dibedakan dan siap dilakukan interpretasi. Hasil dari rotasi faktor tersebut menunjukkan bahwa nilai-nilai loading faktor diantara variabel dengan beberapa faktor telah cukup dibedakan dan siap dilakukan interpretasi.

\section{Interpretasi hasil analisis faktor}

Ketujuh faktor disusun dari 33 variabel penelitian dan dapat diringkas/disederhanakan pada Tabel 5. Masing-masing faktor telah terbentuk yang terdiri dari variabel-variabel yang diteliti. Variabel-variabel yang berkorelasi kuat (nilai faktor loadingnya besar) dengan faktor tertentu akan memberikan inspirasi penamaan faktor bersangkutan. 
Tabel 5. Pembagian variabel ke dalam faktor dan penamaan faktor

\begin{tabular}{cll}
\hline Faktor & \multicolumn{1}{c}{ Nama Faktor } & \multicolumn{1}{c}{ Variabel Pendukung } \\
\hline 1 & Kualitas Pembimbingan & $\mathrm{X} 17, \mathrm{X} 18, \mathrm{X} 19, \mathrm{X} 20, \mathrm{X} 21, \mathrm{X} 23, \mathrm{X} 24, \mathrm{X} 25$ \\
\hline 2 & Pelayanan dan Lingkungan & $\mathrm{X} 1, \mathrm{X} 2, \mathrm{X} 3, \mathrm{X} 4, \mathrm{X} 5, \mathrm{X} 6, \mathrm{X} 7, \mathrm{X} 8$ \\
\hline 3 & Kemampuan Mahasiswa & $\mathrm{X} 11, \mathrm{X} 12, \mathrm{X} 13, \mathrm{X} 14, \mathrm{X} 15, \mathrm{X} 16, \mathrm{X} 33$ \\
\hline 4 & Motivasi & $\mathrm{X} 29, \mathrm{X} 31, \mathrm{X} 32, \mathrm{X} 34$ \\
\hline 5 & Responsif & $\mathrm{X} 22, \mathrm{X} 26, \mathrm{X} 27$ \\
\hline 6 & Pelibatan oleh Pembimbing & $\mathrm{X} 9, \mathrm{X} 10$ \\
\hline 7 & Gelar dan Prestis & $\mathrm{X} 28$ \\
\hline
\end{tabular}

Faktor pertama (faktor kualitas pembimbingan) adalah proses interaksional dua arah yang terdiri dari mahasiswa dan pembimbing untuk intensif berhubungan satu sama lain dengan semangat profesionalisme, saling hormat, kolegialitas dan keterbukaan pikiran.

Faktor kedua yaitu pelayanan dan lingkungan kampus yang kondusif diberikan kepada mahasiswa bertujuan untuk kelancaran belajar mengajar, misalnya dengan meningkatkan kualitas pelayanan administrasi akademik, maupun memberikan pelatihan-pelatihan yang sifatnya reguler.

Kemampuan mahasiswa sebagai faktor ketiga merupakan keterampilan interpersonal dalam komunikasi, teknik menulis, terampil menggunakan sistem informasi dalam mencari literatur. Sealin itu meliputi keterampilan kerja mahasiswa yang independen, multitasking, cepat, dan tepat dalam melakukan kegiatan penelitian.

Faktor motivasi merupakan faktor keempat yang meliputi kompetensi dan kapasitas intelektual, dukungan keluarga serta gigih, bertanggung jawab, dan berkomitmen.

Faktor kelima dengan nama responsif untuk memperbaiki segera umpan balik dalam pembimbingan secara tepat waktu dan intens. Pelibatan oleh pembimbing merupakan faktor keenam yaitu keterlibatan mahasiswa dalam mengambil keputusan penelitian. Faktor terakhir gelar dan prestis yaitu nama baru dari faktor ketujuh.

Faktor responsif, pelibatan oleh pembimbing, serta gelar dan prestis merupakan penamaan baru yang sebelumnya variabel-variabel di dalamnya tergabung di dalam motivasi dan kualitas pembimbingan. Keseluruhan variabel-variabel penelitian yang telah terbentuk mempunyai korelasi positif. Hal ini berarti nilai faktor loading dianggap siginifkan untuk ukuran contoh 364 responden.

Faktor kemampuan mahasiswa, motivasi, responsif, serta gelar dan prestis merupakan faktor internal dari dalam diri mahasiswa. Faktor eksternal yang dikelompokkan sebagai faktor yang mempengaruhi penyelesaian studi terdiri dari kualitas pembimbingan, pelayanan dan lingkungan, dan pelibatan oleh pembimbing.

\section{Analisis Faktor-faktor yang Mempengaruhi Penyelesaian Tugas Akhir}

Analisis faktor-faktor yang mempengaruhi penyelesaian tugas akhir dilakukan dengan pengumpulan data kuesioner di Institut Pertanian Bogor. Untuk melihat pengaruh bebas yang diperoleh dari analisis faktor, yaitu faktor kualitas pembimbingan, pelayanan dan lingkungan, kemampuan mahasiswa, motivasi, responsif serta gelar dan prestis. Penelitian Sharrif (2015, p.258-260) melakukan penelitian bahwa faktor-faktor internal dan eksternal yang berkontribusi terhadap penyelesaian tigas akhir, yaitu: kelembagaan/organisasi yang mendukung sumber daya fisik, keterampilan penelitian, penelitian kerja, supervisi, motivasi dan demotivasi. Analisis yang dilakukan dengan regresi linier berganda untuk menghasilkan suatu model regresi yang baik. 


\section{Uji Asumsi Klasik}

Analisis dengan regresi linier berganda dilakukan setelah pengujian klasik yang terdiri atas uji normalitas, uji homoskedastisitas, dan uji multikolinieritas. Hal ini dilakukan agar dapat dilakukan perbaikan apabila terjadi penyimpangan dalam pengujian asumsi klasik. Evaluasi yang pertama dilakukan untuk uji asumsi klasik adalah Uji Multikolinieritas.

Berdasarkan Tabel 6, uji ini dilakukan dengan melihat nilai VIF dimana seluruh variabel independen bernilai kurang dari $10(\mathrm{VIF}<10)$. Hal ini menunjukkan bahwa model tersebut terbebas dari masalah multikolinieritas. Uji heteroskedastisitas dan uji normalitas dapat dilihat dengan melihat secara langsung output program atau grafik plot. Dapat dilihat bahwa tidak ada pola tertentu dari titik-titik yang dihasilkan menyebar, sehingga model tersebut terbebas dari masalah heteroskedastisitas (Gambar 2). Sebaran data yang disajikan pada Gambar 3 berupa titik-titik yang dihasilkan dalam grafik plot.

Tabel 6. Uji multikolinieritas

\begin{tabular}{lcc}
\hline \multicolumn{1}{c}{ Model } & \multicolumn{2}{c}{ Collinearity Statistics } \\
& Tolerance & VIF \\
\hline Kualitas Pembimbingan (X1) & 0,665 & 1,505 \\
Pelayanan dan Lingkungan (X2) & 0,756 & 1,323 \\
Kemampuan Mahasiswa (X3) & 0,751 & 1,332 \\
Motivasi (X4) & 0,751 & 1,331 \\
Responsif (X5) & 0,773 & 1,293 \\
Pelibatan oleh Pembimbing(X6) & 0,771 & 1,297 \\
Gelar dan Prestis (X7) & 0,960 & 1,041 \\
\hline
\end{tabular}

Sumber: Hasil Olahan (2019)

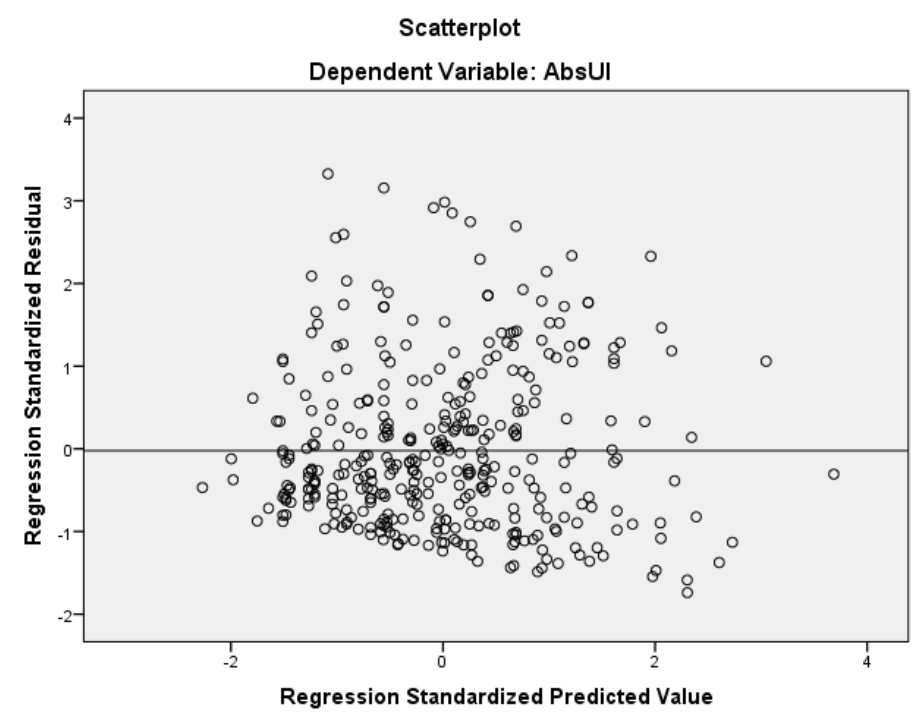

Gambar 2. Grafik Scatterplot

Uji normalitas menunjukkan bahwa sebaran tersebut bergerombol mengikuti garis diagonal grafik, sehingga dapat diambil kesimpulan bahwa model ini terbebas dari masalah normalitas. Model regresi penyelesaian masa studi telah melalui asumsi klasik sehinggga model ini dapat digunakan.

Koefisien determinasi yang diperoleh dalam penelitian ini sebesar 0,24. Ini menunjukkan bahwa 24 persen dari penyelesaian masa studi mahasiswa magister SPs IPB mampu dijelaskan 
secara serentak oleh faktor kualitas pembimbingan, pelayanan dan lingkungan, kemampuan mahasiswa, motivasi, responsif, pelibatan oleh pembimbing serta gelar dan prestis. Sisanya sebesar 76 persen dijelaskan oleh variabel-variabel lain di luar model.

Koefisien determinasi yang diperoleh dalam penelitian ini sebesar 0,24. Ini menunjukkan bahwa $24 \%$ dari masa studi mahasiswa SPs IPB untuk menyelesaikan tugas akhir mampu dijelaskan secara serentak oleh faktor kualitas pembimbingan, pelayanan dan lingkungan, kemampuan mahasiswa, motivasi, responsif, pelibatan oleh pembimbing serta gelar dan prestis.

Normal P-P Plot of Regression Standardized Residual

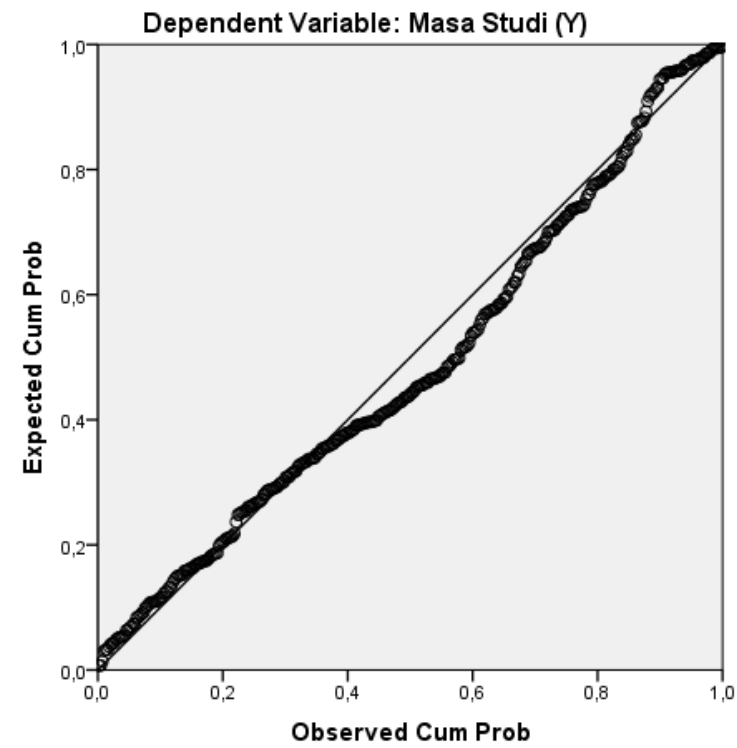

Gambar 3. Sebaran data pada grafik plot

Uji statistik $\mathrm{F}$ dilakukan untuk mengetahui adanya pengaruh variabel independen mempunyai pengaruh secara simultan terhadap variabel dependen. Dari hasil regresi diperoleh faktor-faktor yang mempengaruhi penyelesaian tugas akhir diperoleh $\mathrm{F}$ hitung sebesar 16,062 dengan nilai signifikan sebesar $0,000<0,05$, maka tolak $H_{0}$. Nilai $F_{\text {hitung }}(16,062)>F_{\text {tabel }}(2,04)$, hal ini berarti bahwa variabel independen secara keseluruhan berpengaruh signifikan terhadap variabel dependen (masa studi) dengan taraf nyata 5 persen.

Tabel 7. Hasil uji koefesien Regresi Linier

\begin{tabular}{lrrrc} 
Model & B & Std. Error & \multicolumn{1}{c}{ Sig. } \\
\hline Konstanta & 45,986 & 4,076 & 11,281 & 0,000 \\
Kualitas Pembimbingan (X1) &,- 653 &, 655 &,- 998 & 0,319 \\
Pelayanan dan lingkungan (X2) & 1,348 &, 646 & $2,086^{*}$ & 0,038 \\
Kemampuan Mahasiswa (X3) &, 278 &, 735 &, 379 & 0,705 \\
Motivasi (X4) &, 104 &, 843 &, 123 & 0,902 \\
Responsif (X5) & $-4,531$ &, 503 & $-9,006^{*}$ & 0,000 \\
Pelibatan oleh Pembimbing (X6) &,- 236 &, 537 &,- 440 & 0,660 \\
Gelar dan Prestis (X7) &,- 081 &, 333 &,- 242 & 0,809 \\
\hline
\end{tabular}

Keterangan :

*Taraf Uji Nyata 5\%

Dari hasil signifikasi, maka diperoleh persamaan regresi sebagai berikut: $\mathrm{Y}=45,986-0,653 \mathrm{X} 1+1,348 \mathrm{X} 2+0,278 \mathrm{X} 3+0,104 \mathrm{X} 4-4,531 \mathrm{X} 5-0,236 \mathrm{X} 6-0,081 \mathrm{X} 7$ 
Uji statistik $\mathrm{t}$ dilakukan untuk mengetahui pengaruh masing-masing variabel independen yang signifikan secara parsial terhadap masa studi mahasiswa Program Magister SPs IPB. Apabila nilai tersebut kurang dari taraf nyata 5 persen, maka variabel tersebut berpengaruh secara nyata begitu pula sebaliknya. Hasil penelitian (Tabel 7), diketahui bahwa diantara ketujuh variabel bebas yang dispesifikasikan dalam model, dua variabel diantaranya, yakni faktor pelayanan dan lingkungan dan faktor responsif berpengaruh nyata terhadap penyelesaian masa studi mahasiswa program magister SPS IPB, dimana hal ini ditujukkan dengan nilai taraf signifikansi dari masing-masing variabel tersebut besar dari 0.05 yang berarti kedua variabel tersebut berpengaruh nyata terhadap pendapatan pada taraf uji 5 persen.

\section{Konstanta atau Intersep}

Berdasarkan hasil estimasi data dalam model regresi diperoleh nilai konstanta sebesar 45,986 yang bernilai positif. Hal ini menunjukkan bahwa tingkat penyelesaian masa studi naik ketika variabel penjelas tetap. Berikut penjelasan terhadap interpretasi hasil regresi variabel bebas:

1. Faktor Kualitas Pembimbingan

Berdasarkan hasil uji t pada faktor sifat dan kualitas pemimbingan (X1), diketahui nilai koefisien regresi linier pada variabel X1 menunjukkan angka yang negatif sebesar 0,653. Dengan keputusannya adalah menolak hipotesis alternatif $\left(\mathrm{H}_{\mathrm{a}}\right)$ yang diajukan, yakni faktor sifat dan kualitas pembimbingan berpengaruh negatif dan tidak signifikan terhadap masa studi. Pembimbingan adalah proses interaksional dua arah yang dibutuhkan mahasiswa dan pembimbing untuk berhubungan dalam semangat profesionalisme, menghormati, kolegialitas dan keterbukaan pikiran (Ismail, Abiddin, Hassan, 2011, p.79). Namun pembimbingan saja tidak cukup mempengaruhi penyelesaian masa studi, diperlukan pembimbing dan manajerial seperti pusat-pusat pascasarjana/lembaga bersama-sama untuk mengembangkan pendekatan yang sistematis yang lebih baik untuk mahasiswa (Zaaba, Gunggut, Arapa, Aning, 2015, p.187). 2. Faktor Pelayanan dan Lingkungan

Berdasarkan hasil uji t pada variabel faktor pelayanan dan lingkungan (X2) diketahui nilai koefisien regresi linier pada variabel X2 menunjukkan angka yang positif sebesar 1,348. Dengan keputusannya adalah menerima hipotesis alternatif (Ha) yang diajukan, yakni faktor pelayanan dan lingkungan berpengaruh signifikan terhadap masa studi. Semakin meningkatnya faktor pelayanan dan lingkungan, maka akan meningkatkan penyelesaian masa studi. Hal ini dilakukan dengan meningkatkan penyediaan dan kualitas layanan responsif (perpustakaan, sarana pembelajaran, akses internet, layananan administrasi), intensitas workshop/seminar di kampus, institusi dan lingkungan belajar (Leijen, Lepp, Remmik, 2015, p.1), serta dukungan konseling dan karir (Shariff, Kamal, Ramli \& Ahmad, 2015, p.260). Hal yang penting penyelesaian masa studi adalah penguatan sistem pendukung akademik yang berada di lingkungan kampus. Kegiatan akademik pada tahap ujian akhir mahasiswa program magister, dalam penelitian Wamala dan Oonyu (2012, p.135) menjadi penyebab tertundanya penyelesaian studi di Makerere University. Penelitian tersebut menemukan bahwa bahwa dukungan sistem administrasi yang kuat sangat diperlukan dalam membantu penyelesaian studi mahasiswa program pascasarjana tepat waktu, terutama pada aspek-aspek yang berhubungan dengan proses review laporan mahasiswa.

3. Faktor Kemampuan Mahasiswa

Berdasarkan hasil uji t pada faktor kemampuan mahasiswa (X3), diketahui nilai koefisien regresi linier pada variabel X1 menunjukkan angka yang positif sebesar 0,278. Dengan keputusannya adalah menolak hipotesis alternatif $\left(\mathrm{H}_{\mathrm{a}}\right)$ yang diajukan, yakni faktor kemampuan mahasiswa tidak berpengaruh signifikan terhadap masa studi. Hasil ini bertentangan dengan faktor sebelumnya dimana faktor keterampilan atau kemampuan mahasiswa dalam penelitian signifikan sebagai faktor utama yang berkontribusi terhadap penyelesaian masa studi tepat 
waktu (Shariff, Kamal, Ramli \& Ahmad, 2015, p.261). Responden penelitian ini tidak memperhitungkan keterampilan yang dimilikinya sehingga faktor kemampuan mahasiswa tidak memiliki hubungan yang kuat dengan penyeesaian masa studi.

\section{Faktor Motivasi}

Berdasarkan hasil uji t pada faktor motivasi (X4), diketahui nilai koefisien regresi linier pada variabel X1 menunjukkan angka yang positif sebesar 0,104. Dengan keputusannya adalah menolak hipotesis alternatif $\left(\mathrm{H}_{\mathrm{a}}\right)$ yang diajukan, yakni faktor motivasi tidak berpengaruh signifikan terhadap masa studi. Faktor motivasi yang termasuk dalam aspek pribadi dalam penelitian sebelumnya menjadi salah satu faktor signifikan (Pitchforth et al., 2012, p. 129). Namun dalam penelitian ini pada saat mahasiswa bersekolah untuk meningkatkan kompetensi dan kapasitas intelektual, dukungan dari keluarga, sifat bertanggung jawab dan berkomitmen adalah hal yang penting namun tidak menjadi faktor yang utama.

5. Faktor Responsif

Berdasarkan hasil uji t pada faktor responsif (X5), diketahui nilai koefisien regresi linier pada variabel X5 menunjukkan angka yang negatif sebesar 4,531 Dengan keputusannya adalah menerima hipotesis alternatif $\left(\mathrm{H}_{\mathrm{a}}\right)$ yang diajukan, yakni faktor responsif berpengaruh signifikan terhadap masa studi. Jika variabel independen lainnya tetap dan variabel (X5) yakni faktor responsif mahasiswa semakin meningkat terhadap penelitian, maka masa studi akan semakin menurun atau singkat. Hal ini disebabkan karena apabila mahasiswa berinisiatif untuk intens mengikuti bimbingan, hasil perbaikan tepat waktu dan ulet dalam memperbaiki segera feedback dari pembimbing, maka mahasiswa dapat segera menyelesaikan studinya.

6. Faktor Pelibatan Pembimbing

Berdasarkan hasil uji t pada faktor pelibatan (X6), diketahui nilai koefisien regresi linier pada variabel X6 menunjukkan angka yang negatif sebesar 0,236. Dengan keputusannya adalah menolak hipotesis alternatif $\left(\mathrm{H}_{\mathrm{a}}\right)$ yang diajukan, yakni pembimbing melibatkan mahasiswanya untuk melakukan penelitian dan berpengaruh negatif dan tidak signifikan terhadap masa studi.

\section{Faktor Gelar dan Prestis}

Berdasarkan hasil uji t pada faktor pelibatan (X7), diketahui nilai koefisien regresi linier pada variabel X7 menunjukkan angka yang negatif sebesar 0,081. Dengan keputusannya adalah menolak hipotesis alternatif $\left(\mathrm{H}_{\mathrm{a}}\right)$ yang diajukan, yakni faktor gelar dan prestis negatif dan tidak signifikan terhadap masa studi. Mahasiswa membutuhkan penyelesaian studi karena gelar dan prestis, tapi bukan untuk target penyelesaian tepat waktu.

\section{SIMPULAN}

Dari 34 faktor yang diteliti, diperoleh tujuh faktor utama yang berperan dalam penyelesaian studi mahasiswa program magister Sekolah Pascasarjana IPB, yakni: (1) kualitas pembimbingan, (2) pelayanan dan lingkungan, (3) kemampuan mahasiswa, (4) motivasi, (5) responsif, (6) pelibatan oleh pembimbing, serta (7) gelar dan prestis. Analisis lebih lanjut menunjukkan bahwa diantara tujuh faktor hanya ada dua faktor yang signifikan terhadap masa studi yaitu faktor eksternal meliputi pelayanan dan lingkungan serta sikap responsif. Faktor pelayanan diantaranya institusi memberikan fasilitas kepada mahasiswa bertujuan untuk kelancaran belajar mengajar, misalnya dengan meningkatkan kualitas pelayanan administrasi akademik, maupun memberikan pelatihan-pelatihan yang sifatnya reguler serta lingkungan kampus yang alami. Faktor responsif mahasiswa diantaranya inisiatif untuk intens mengikuti bimbingan, hasil perbaikan tepat waktu dan ulet dalam memperbaiki segera feedback dari pembimbing, maka mahasiswa dapat segera menyelesaikan studinya.

\section{Saran}


Penelitian ini perlu dilengkapi dengan analisis kuantitatif yaitu dengan melibatkan data karakteristik mahasiswa seperti usia, rentang waktu dari S1 ke S2, IPK S1, IPK S2, jenis kelamin, perkawinan, pekerjaan, jenis keilmuan PS S2, linearitas, asal PT, kategori BAN PT, jenis kelas, sumber biaya, dan lokasi asal PT S1.

\section{DAFTAR PUSTAKA}

Abiddin, N. Z., Ismail, A., \& Taniredja T. (2013). Enhancing Quality of Higher Education for Graduate Research Students Development. International Review for Education Studies, 5(2).

Ismail, A., Abiddin, N. Z., \& Hassan, A. (2011). Improving the development of postgraduates' research and supervision. International Education Studies, 4(1), 78-89.

Arikunto, S. (2006). Metodologi Penelitian. Yogyakarta. Bina Aksara

Armstrong, S. J., Allinson, C. W., \& Hayes, J. (2004). The Effects of Cognitive Style on Research Supervision: A Study of Student-Supervisor Dyads in Management Education. Academy of Management Learning and Education. Vol. 3, No. 1, 41-6

Asra, A., Utomo, A. P., Asikin, M., \& Pusponegoro, N. H. (2017). Analisis Multivariabel: Suatu Pengantar. Bogor. In Media.

Bourke, S. (2004). Attrition, Completion and Completion Times of PhD Candidates. Paper Presented at the AARE Annual Conference Melbourne, 28 Nov - 2 Dec 2004.

Cooke, D., Sims, J., \& Peyrefitte, J. (1995). The Relationship between Graduate Student Attidudes and Attrition. Journal of Psychology, 129, 677-688.

Divjak, B., \& Oreski, D. (2009). Prediction of Academic Performance Using Discriminant Analysis, Proceedings of the ITI $200931^{\text {st }}$ Int. Conf. on Information Technplogy Interfaces, June 22-25, Cavtat, Croatia.

Earl-Novell, S. (2006). Determining The Extent to Which Program Structure Features and Integration Mechanisms Facilitate or Impede Doctoral Student Persistence in Mathematics. International Journal of Doctoral Studies, 1, 45-57.

Ghozali, I. (2011). Aplikasi Analisis Multivariate dengan Program SPSS. Semarang: Badan Penerbit Universitas Diponegoro.

Ihsan, H., \& Zaki, A. (2015). Analisis Faktor-faktor yang Menghambat Penyelesaian Studi Mahasiswa FMIPA UNM. Jurnal Scientific Pinisi, 1(1).

Latona, K., \& Browne, M. (2001). Factors Associated with Completion of Research Higher Degrees. Higher Education Series, Report No.37, May, Higher Education Division, Department of Education, Training and Youth Affairs, Canberra.

McCormack, C. (2005). "Is Non-completion a Failure or a New Beginning? Research Noncompletion from a Student's Perspective." Higher Education Research and Development, 24(3), 233-247.

Mohammadi, A., \& Sharififar, M. (2016). Attributions for Success and Failure: Gender and Language Proficiency Differences among Iranian EFL Learners, 6(3), 518-524.

Mugimu, C. B., Nsubuga, Y. K., \& Jacob, W. J. (2009). Higher Education in Uganda: The Role of Community Colleges in Educational Delivery and Reform. Community College Models, 335-358.

Pitchforth, J., Beames, S., Thomas, A., Falk, M., Farr, C., Gasson, S., Thamrin, S. A., \& Mengersen, K. 2012. Factors Affecting Timely Completion of a Phd: A Complexm Systems Approach. Journal of the Scholarship of Teaching and Learning, 12(4), 124-135.

Putri, D. K. S., \& Savira, S. I. (2013). Pengalaman Menyelesaikan Skripsi: Studi Fenomenologis pada Mahasiswa Psikologi Universitas Negeri Surabaya. Character, 2(2).

Sakurai, Y., Pyhalto, K., \& Ylanne, S. L. (2012). Factors Affecting International Doctoral Students’ Academic Engagement, Satisfaction with Their Studies, and Dropping Out. International Jurnal for Researcher, 3(2).

Santoso, S. (2014). Statistik Multivariat. Elex Media Komputindo, Jakarta.

Seagram, B., Gould, J., \& Pyke, S. (1998). An Investigation of Gender and Other Variables on Time to Completion of Doctoral Degrees, Research in Higher Education, 39(3), 319-335.

Shariff, N. M., Ramli, K. I., \& Ahmad, R. (2015). Factors Contributing to the Timely Completion of PhD at the Malaysian Public Higher Educational Institutions. International Journal of Humanities Social Sciences and Education (IJHSSE), 2(1), 256-263.

Smith, R. S., Cameron, C., \& Quigg, R. (2017). Factors Contributing to High PhD Completion Rates: A Case Study in a Research Intensive University in New Zealand. Assessment \& Evaluation in Higher Education.

Spaulding, L. S., \& Rockinson-Szapkiw, A. J. (2012). Hearing Their Voices: Factors Doctoral Candidates Attribute to their Persistence. International Journal of Doctoral Studies, 7, 199-219. 
Ssegawa, J. K., \& Rwelamila, P. D. (2009). The research skill factor as a cause for high postgraduate attrition rate. Journal of Engineering, Design \& Technology, 7(3), 293-322.

Sudira, P., \& Soenarto, P. (2015). Evaluasi Kompetensi Penulisan Tesis Mahasiswa S2 Program Studi Pendidikan Teknologi dan Kejuruan. Jurnal Penelitian dan Evaluasi Pendidikan, 19(1).

Syakir, M. J., \& Pardjono. (2015). Pengeruh Kepemimpinan Kepala Sekolah, Motivasi Kerja, dan Budaya Organisasi terhadap Kompetensi Guru SMA. Jurnal Penelitian dan Evaluasi Pendidikan, 3(2).

Wamala R, Oonyu JC. 2012. Completion Time Dynamics for Master's and Doctoral Studies at Makerere University. Contemporary Issues in Education Research, 5(2):131-137.

Zaaba, Z., Gunggut, H., \& Aning, A. (2015). Postgraduate Research Completion: Student Expectation and Inspiration. Procedia - Social and Behavioral Sciences 202 (2015), 181 - 188 